\title{
Correction to: Thai Handwritten Recognition on BEST2019 Datasets Using Deep Learning
}

\author{
Rapeeporn Chamchong (D), Umaporn Saisangchan, \\ and Pornntiwa Pawara $(D$
}

\section{Correction to:}

Chapter "Thai Handwritten Recognition on BEST2019

Datasets Using Deep Learning" in: P. Chomphuwiset et al. (Eds.): Multi-disciplinary Trends in Artificial Intelligence, LNAI 12832, https://doi.org/10.1007/978-3-030-80253-0_14

The word 'encoded' has been updated to 'decoded' in section 4.3 of the chapter. The ground truth of image 6 in Table 3 has been updated from สุบภาพแบ็งแรงนะคร้าบ to ทุกสีงทีเกิดบึนมักมีเหตุผลเสมอ. 